\title{
$19 \Delta$
}

\section{Ditransitive Constructions in Zaza Langauge}

\author{
Zaza Dilinde Çift Geçişli Fiillerin Yapısı
}

\author{
illyas ARSLAN \\ Dr. Öğr.üyesi Munzur Üniversitesi, \\ Edebiyat Fakültesi, Zaza Dili ve Edebiyatı \\ arslanelias@gmail.com \\ https://orcid.org/0000-0002-1364-7669
}

\section{Araștırma \& Yayın Etiği \\ Bu makale en az iki hakem tarafindan incelenmiș, iThenticate yazılımı ile taranmış, araștırma yayın ve etiğine aykırılık tespit edilmemiștir.}

\section{BY-NC 4.0}

Bu makale Creative Commons Attribution-NonCommercial License altında lisanslanmıștır.

This paper is licensed under a Creative Commons Attribution-NonCommercial License

\section{Research \& Publication Ethics}

This article was reviewed by at least two referees, a similarity report was obtained using iThenticate, and compliance with research/publication ethics was confirmed.

\section{Copyright $\odot$}

Sakarya Üniversitesi, Sosyal Bilimler Enstitüsü, Sakarya/TÜRKIYE

Sakarya University, Institute of Social Science, Sakarya/TURKEY

\section{Atıf/Citation}

Arslan, ilyas. "Ditransitive Constructions in Zaza Langauge". Akademik İncelemeler Dergisi 16 / 2 (Ekim 2021): 83-98.

https://doi.org/10.17550/akademikincelemeler.946671

Makale Türü/Article Type: Araştırma Makalesi/Research Article

Geliş Tarihi/Date Received: 01.06.2021

Kabul Tarihi/Date Accepted: 05.10.2021

Yayın Tarihi/Date Published: 15.10.2021

ISSN: $\quad 1306-7885$

E-ISSN: $2602-3016$ 


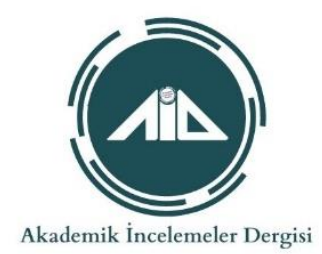

\title{
Ditransitive Constructions in Zaza Langauge
}

\begin{abstract}
Languages group verbs in different ways. Because of the ergative feature of Zazaki, it plays a big role whether the verbs are transitive or intransitive. Zaza Language introduces some pronouns to distinguish double-transitive verbs from transitive and intransitive verbs. In some linguistic works, the terms transitive and ergative are used synonymously. This article aims to scrutinize ditransitive constructions in the Zaza language, which has some interesting syntactic elements in these structures. They are mostly pronouns in combination with directions. Several pronouns replace indirect object. On the one hand, the goal of this study is to find out the functions of these pronouns. The semantic content of these pronouns decides which pronouns may appear in a specific position. They can appear with or without directions. Only the pronouns such as $\mathrm{Cl}$ can alone replace a NP, the other ones need a direction for this replacing. On the other hand, this study discusses the morphosyntactic and semantic realizations in ditransitive constructions. While these pronouns do not syntactically follow the same word order, they can semantically be classified into two groups.
\end{abstract}

Keywords: Morphosyntax, Ditransitive verbs, Recipient, Zaza, İranian languages.

\section{Zaza Dilinde Çift Geçişli Fiillerin Yapısı}

\section{Öz}

Diller farklı yöntemlerle fiilleri gruplandırırlar. Zazacanın ergatif özelliğinden dolayı fiillerin geçişli veya geçişssiz olmaları büyük rol oynamaktadır. Zaza Dili çift geçişli fiilleri geçişli ve geçişsiz fiilerden ayırdetmek için bazı zamirler devreye koyar. Bazı dilbilimsel eserlerde geçişli ve ergatif kavramı eşanlamlı olarak kullanılır. Bu makale, bu yapılarda bazı ilginç sözdizimsel unsurlara sahip olan Zaza dilindeki çift geçişli yapıları incelemeyi amaçlamaktadır. Çift geçişli fiilerdeki hedef ya da indirek nesnenin yerine kullanılan birçok zamir mevcuttur. Bu zamirler çoğunlukla yön partikelleri ile kombine edilirler. Bir yandan, bu çalışmanın amacı bu zamirlerin işlevlerini ortaya çıkarmaktır. Bu zamirlerin anlamsal içeriği, hangi zamirlerin belirli bir konumda görünebileceğine karar verir. Yön partikelleri Yönlü veya yönsüz görünebilirler. Sadece cl gibi zamirler tek başına bir NP'nin yerini alabilir, diğer zamirler bunun yerine geçmek için bir yön partikeline ihtiyaç duyar. Öte yandan, bu çalışma, dönüşümlü yapılarda morfosentaktik ve anlamsal gerçekleşmeleri tartışmaktadır. Bu zamirler sözdizimsel olarak aynı kelime sırasını takip etmese de, anlamsal olarak iki gruba ayrilabilirler.

Anahtar Kelimeler: Morfosentaks, Geçişli fiiller, Hedef Nesnesi, Zaza, İrani Diller. 


\section{Introduction}

Although there are many accents of the Zaza Language, which belongs to the Northwestern Iranian language group, it is possible to divide it into two dialects. Some accents in the Southern dialect are farther apart though the accents of the Northern dialects are closer to each other. Due to different accents of the Southern dialect, the data given in this article belongs to the Northern dialect which does not vary widely in itself. Another reason for using the Northern data more is that the author has a good knowledge of this region. The examples from the Southern dialect are also included in order to show both the similarities and the basic changes in this field.

Conventionally, ditransitive verbs have three argument positions. 'A ditransitive construction is defined here as a construction consisting of a (ditransitive) verb, an agent argument (A), a recipient-like argument (R), and a theme argument (T)' (Malchukov, 2007: 3). The using of some pronouns for indirect object in Zazaki and the functions of these pronouns constitute complex verb infinitives. Recipient pronouns can give a different meaning to the verb, amplify its meaning, or determine the style of the action and its endpoint. Furthermore, these pronouns make the structure ditransitive to add a requisite constituent to a transitive verb (see table 4.1). Although there are a lot of ditransitive verbs, the examples will be presented more on the verb kerdene 'to do, to make' as it can be used in all combinations.
a. Ey deşi boax kerdi 'He painted the walls.'
boax kerdene 'to paint' (A,P)
b. Ey boax kerd dêsu ra 'He put the paint on the walls.'
pi ra kerdene 'to put' $(A, T, R)$
c. Ae kar kerd 'She worked.'
kar kerdene 'to work' (A,P)
d. Ae Xıdır kerd kar 'She helped Xıdır get a job.'
cl kerdene 'to do inside' $(A, T, R)$
e. İne ma ra va(t) 'They said to us.'
cl ra vatene 'to say' $(\mathrm{A}, \mathrm{T}, \mathrm{R})$
f. Keyna fistan girot 'The girl bought/took the skirt'
gırotiş 'to buy/to take' (A,P)
g. Keyna fistan girot pı ra 'The girl wore the skirt'
pı ra girotiş 'to wear' $(\mathrm{A}, \mathrm{T}, \mathrm{R})$

The word order is $\mathrm{S}+\mathrm{O}+\mathrm{V}$ in transitive verbs, while it is Agent+Theme+Verb+Recipient $\left(\mathrm{S}+\mathrm{O}_{\mathrm{D}}+\mathrm{V}+\mathrm{O}_{\mathrm{i}}\right)$ in ditransitive verbs due to the recipient object. Direct object which is a syntactic category corresponds to the theme in semantics, whereas indirect object corresponds to the recipient. In Zaza Language, except in one case, direct objects precede verbs and indirect objects follow verbs. Another important feature of the recipient object is that it is always marked by oblique case. The use of $t l$ or $\mathrm{Cl}$ for $\mathrm{pl}$ assigns different meanings to the sentence. It also renders the sentence meaningless according to context. The reason for using $p_{l}$ for the direct object is to point out that the motion which starts from the direct object and turns towards the recipient object ends on the surface of the recipient (1.1b). As for in (1.1d), cl can be used for kar 'work'. While the other pronouns cannot be used alone, $\mathrm{Cl}$ is used both alone and with other particle combinations. Another feature of $c l$ is that it makes an exception that the recipient object can be located before the verb when used with the direction particle in word order. The recipient appears before the verb in the verbs such as $\mathrm{Cl}$-ra vatene 'to say to someone' and cl-ra kerdene 'to cut off from something', whose objects are null and the verbs are inflected according to 
the null objects in past tense (1.1e). While there are phonological sound changes in the examples (1.1f) (1.1g) from the Southern dialect, there is no syntactic change.

Figure 1.2. The general structure of ditransitive constructions (Malchukov 2007: 4)
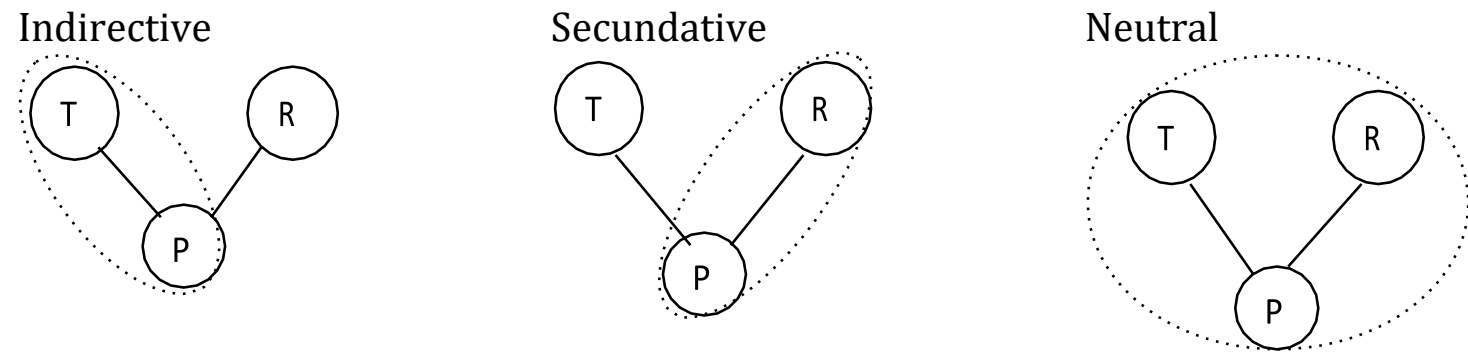

Source: Andrej Malchukov \& Martin Haspelmath \& Bernard Comrie. Ditransitive constructions: A typological overview. Studies in Ditransitive Constructions: A Comparative Handbook. (2007):45.

There are three basic structures in ditransitive verbs. 'Indirect object alignment or indirective alignment: The $\mathrm{R}$ is treated differently from the $\mathrm{P}$ and the $\mathrm{T}(\mathrm{T}=\mathrm{P} \mathrm{R})$. Such constructions are also called "dative constructions" or "indirect object constructions".' (Malchukov 2007: 3). The patient of transitive verb and the theme of ditransitive verb have the same features, while the recipient has a different feature (Haspelmath 2015: 22). The inflection of verbs according to direct object in past tenses in Zazaki is another common feature of transitive and ditransitive verbs. Apart from indirective alignment, secundative is available in syntactically ergative languages, and neutral alignment is also available in some languages. Zazaki, which is morphologically an split ergative language, has an indirective alignment since it is syntactically accusative (Arslan 2016, 2017).

\section{Recipient/Indirect Object Pronouns}

In Zazaki, the recipient object pronouns are also used in intransitive verbs, but this does not add a new argument to the intransitive verb. The intransitive verb has one argument in any case. When these pronouns are added to transitive verbs, there is usually a position for a new valence and the verb becomes ditransitive. The recipient object pronouns used for the position of the recipient in ditransitive verbs are also a component of the infinitive of the verb. While the collective pronouns of the object pronouns are used for the direct object $p \hat{e}, t \hat{e}, c \hat{e}$, the object pronouns giving the outer and inner meaning are used for the recipient object. Table 2.1 (Selcan 1998: 426) below shows the details of the pronouns.

Table. 2.1.The semantic of recipient object pronouns

\begin{tabular}{|c|c|c|c|}
\hline & /ê/ & $/ 1 /$ & /e/ \\
\hline$/ \mathrm{p} /$ & pê & $\mathrm{pl}$ & pe \\
\hline$/ \mathrm{t} /$ & tê & $\mathrm{tl}$ & te \\
\hline$/ \mathrm{c} /$ & cê & $\mathrm{Cl}$ & - \\
\hline & collective & oute & in \\
\hline
\end{tabular}

The indirect object pronouns, which vary according to their semantic meaning, are used in ditransitive sentences. These will be analyzed in detail. As $\mathrm{Cl}$ is comprehensive, it can be used with a verb per se, while others need a particle. Most of the verb prefixes are used 
with directional particles, but their functions are different. Two particles in the same style such as pe, te or $r a$ and $r o$ cannot be used together. Those with different functions in terms of content can be used together. In the following table 2.2 (Selcan 1998: 429), the combination of the prefixes is given on the one hand, and the motion directions of the directional particles are given on the other hand. One of the direction particles which is mostly used with indirect object is $r a$. As for we, it has no combination with any recipient pronouns.

Table 2.2. The combination of the verb prefixes

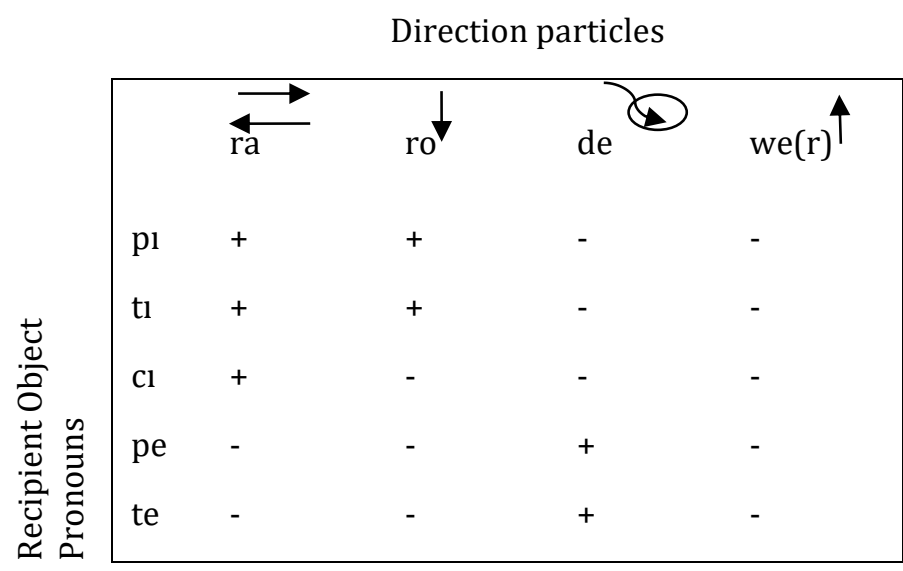

These pronouns cannot be used per se. They only function in connection with the verb that they come before. The recipient object pronouns $(c l, p l, t l, p e, t e)$ that appear as the verb prefixes are divided into two groups: Those that can be used per se $(c l)$ and those that are used with a directional particle $(c l, p l, t l, p e, t e)$. Direct use of the recipient object whose information is previously shared between the sender-receiver means that the recipient object is known by the informant. For example, speech partners know what the recipient object is in the sentences ae uxwe kerde lazeki (pI) ro 'she washed the boy' ey desteke kerde derzêni ( $t$ I) ra 'he put the thread on the needle' even when the pronouns are used. In the examples below (2.1), the use of pronouns is also given.
a. Xıdiri ron kerd non ra
$\rightarrow$ Xıdıri ron kerd pı ra
'Xıdır has greased bread'
b. Heseni la kerd derzêni ra
$\rightarrow$ Heseni la kerd tı ra
'Hesen threaded the needle'
c. Çêneke po rê ho cı ra kerd
$\rightarrow$ Çêneke porê ho cı ra kerd
'The girl cut her hair'
d. Lazeki min kerd hard de
$\rightarrow$ Lazeki min kerd pe de
'The boy pounded the nail into the ground'
e. Pisinge oda de ci kerd $\quad \rightarrow$ Pisinge te de ci kerd
'The cat defecated in the room'

As others can only make one combination with directional particles, the pronouns $p l$ and $t ı$ (see Tab. 2.2) have most combinations. They can be used with vertical ro and horizontal 
$r a$ directional particles. $P l$ is when an actant reaches the surface of the recipient object (2.1a), whereas $t l$ is passing into or through the recipient object (2.1b). The action at $t l$ can also exit from the other side of the recipient object and continue. Unlike other pronouns, $\mathrm{Cl}$ can both form an infinitive with a verb without a directional particle, $\mathrm{Cl}$ kerdene 'to do in, to fill in', and make a combination with directional particles (2.1c). In some cases, $t \imath$ is also used in the Southern dialect for $c l$ used in the Northern dialect, as in $\mathrm{Cl}$ ra vatene $\rightarrow$ tı ra vatiş "to say something to someone". These local differences do not cause any functional changes. Even in some accents of the Southern dialect, the pronoun $\mathrm{Cl}$ makes the distinction between masculine, feminine and plural. $\mathrm{Cl}$ appears for masculine, $c a$ for feminine, and cin for plural objects. This distinction does not appear in the Northern dialect. $P e$ and $t e$, which can be used with particle $d e$, cannot be used alone or with other directional particles. In $p e$, the action does not end on the surface of the recipient object but continues into it (2.1d). The particle te is used for the stationary state inside the object, while the particle pe refers to a motion directed towards the surface of the object. Since te is a part of the verb in some verbs, it does not leave its place to any objects.

Figure 2.1.The sentence structure with ditransitives

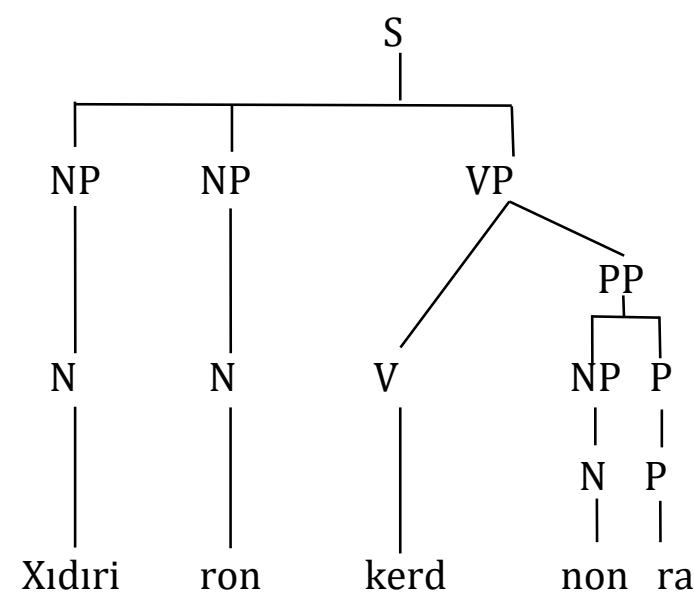

In the Northern dialect, the recipient pronouns do not differentiate genus, numerus and casus, but this distinction is made when personal pronouns are used for them. This distinction is clearly seen in the sentence XIdiri ron kerd ey ra in the same sense for (2.1). The pronoun ey is the 3rd singular masculine in the oblique case. Furthermore, these recipient pronouns are used for NPs which are only 3rd singular and 3rd plural. Pl ra for to $\mathrm{ra}$ in the sentence Piyê to çeket da ey ra 'Your father put him on a jacket' cannot be used. Thus, it is usual to distinguish two basic types of ditransitive verbs: the verbs of change of possession (ditransitive proper such as 'give') and the verbs of change of location or caused motion such as 'send' (Malchukov 2010: 48).

There is no structural difference between Northern and Southern dialects in ditransitive verbs. While the same recipient pronouns are generally used in all Zazaki speaking regions, there is exceptionally the pronoun $\mathrm{Cl}$, which is used in different meanings, in the Northern dialect. Although the pronoun $t$ is used with some verbs in the Southern dialect for the pronoun $\mathrm{Cl}$, there is no syntactic change. 


\section{The Morphosyntax of Ditransitive Constructions}

\subsection{The İnflection Of Verbs And The Distribution Of Cases}

$S$ is defined as a subject of a intransitive verb. This is marked by nominative case in all tenses. The A which is the subject of a transitive and ditransitive verb is also marked by nominative case like $S$ in present tense. When past tense is used, case changes occur in the arguments of transitive verbs. Since the object of the transitive verbs (Patient) and the object of the ditransitive verbs (Theme) are inflected with the verb, they become nominative. As for $\mathrm{A}$, it becomes oblique. $\mathrm{P}$ and $\mathrm{T}$ are regularly marked by the oblique and placed preverbally, while $\mathrm{R}$ is always postverbal and never has agreement. Cases and agreements are given in tab. 3.1.

Table 3.1.Cases and verb inflections

\begin{tabular}{|l|l|l|l|}
\hline Past Tense & Case & Inflection \\
\hline verb & Nominative & Oblique & \\
\hline intransitive & Subject & & Subject \\
\hline transitive & Patient & Agent & Patient \\
\hline ditransitive & Theme & $\begin{array}{l}\text { Agent } \\
\text { Recipient }\end{array}$ & Theme \\
\hline
\end{tabular}

In Table 3.1 above, the distributions of cases and inflections are given by taking the past tense form of sentences into consideration. In present tense, the verb is inflected according to Subject and Agent, whereas Patient and Theme are directly linked to the verb in the past tense. Therefore, these constituents are marked by nominative case. Likewise, the Theme is marked by oblique case as well as the recipient in ditransitive verbs in the present tense. The thematic roles of verbs are also given in example (3.1). The agreement is not on the recipient in no case.

a. Kitab mekteb de waniya- $\varnothing$

book.NOM school.OBL in readPAST-3sgM

SUBJECT ADJUNCT

'The book was read in the shool.'

b. Malim-i kitab-i wend-i

teacher-OBL book-PL.NOM readPAST-3pl

AGENT PATIENT

'The teacher $(\mathrm{m})$ read the books.'

c. Malim-i kılıt kerd- $\varnothing$ çêver ra $\rightarrow$ Malim-i kılıt kerd tı ra

teacher.OBL.M key.NOM doPAST-3SgM door.OBL DP

AGENT THEME RECIPIENT

'The teacher (m) put the key on the door.' 
d. Malime kitab da- $\varnothing \quad$ talebe-y $\rightarrow$ Malime kitab da cl

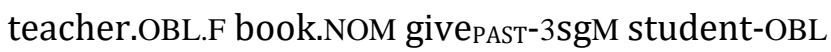

AGENT THEME $\quad$ RECIPIENT

'The teacher (f) gave the book to the student.'

Directional particles $r a$, ro, we and de mark the constituents that they are used with as oblique case. But this is not the only reason why the $\mathrm{R}$ in (3.1c) is in oblique case. The $\mathrm{R}$ is also marked by oblique in (3.1d) when the recipient object is used alone without directional particles. As in the example $O$ şi çê 'he went home', the use of any recipients in the sentence does not change the intransitiveness of the verb in (3.1a). This is because this adjunct constituent does not have a valence property. The distinction animate/inanimate is made in oblique case. While the animates receive the suffix /-i/, this suffix is not used for inanimate and becomes $/-\varnothing /$. Besides, indirective structure $(T=P$, R) occurs when transitive (3.1b) and ditransitive (3.1c) (3.1d) are compared.

\subsection{Passivization}

While passivization occurs on Theme and Patient in Zazaki, it cannot occur on Recipient. This is called indirective passivization. Passivization occurs in three ways. (i) The /-i/ morpheme which is still found in Zaza language, remaining from the old Iranian languages historically, though it has been lost in many modern Iranian languages (ii) the auxiliary verb amaene and (iii) the copular verb (biyaene) that only passivizes the verb kerdene. Semantically and morphologically, it is not possible to passivize with the /-i/ suffix in some verbs. The auxiliary verb usually is used in these verbs. There are also cases in which (i) and (ii) are used as alternation, while (iii) is only possible in one case. Derz-iya-ene and des-t-ene amaene are used as passive forms of the verb des-t-ene 'to sew', while the auxiliary verb is only used for the verb ardene 'to bring'. This is because the verb ariyaene does not have a meaning. The passive roots of the verbs also form the root of the present tense. Destene 'sew', derz-iya-ene 'to be sewn', o derz-en-o 'he sews'. The examples of passivization are given below (3.2b), (3.2d), (3.2f).

a. Heseni kemere est-e uxiwe cl estene

Hesen-OBL stone.NOM throw ${ }_{\mathrm{PAST}}$-3SgF water.OBL 'to throw'

AGENT THEME RECIPIENT

'Hesen threw the stone into the water'.

b. Kemere erz-iy-e uxiwe cl erziyaene

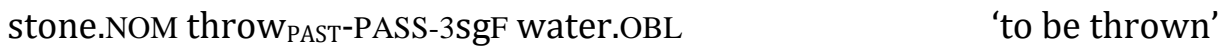

\section{SUBJECT $\quad$ ADJUNCT}

'The stone is threw into the water'.

c. Hosta-y boax kerd dês ra pırakerdene

constructor-OBL paint.NOM doPAST.3sgM wall.OBL DIR 'to put'

AGENT THEME VERB RECIPIENT

'The constructor put on the paint on the wall'. 

d. Boax
bi
dês ra
pı ra biyaene
paint.NOM be PAST $_{\text {-3SgM wall.OBL DIR }}$
'to be put'
SUBJECT
ADJUNCT
'The paint was put on the wall'.
e. Xıdıri dês boax kerd
boax kerdene
Xıdır-OBL wall.NOM paint
dopaST.3sgM
'to paint'
AGENT PATIENT
'Xıdır painted the wall'.
f. Dês boax bi
boax biyaene
wall.NOM paint be PAST $^{-3}$ sgM
'to be painted'

SUBJECT

'The wall was painted'.

All three forms of passivization cannot use with all verbs. The suffix /-i/ can be replaced by active suffixes like $-t,-n$, whereas the lexical auxiliary verb amaene is used as an alternation for the suffix /-i/. As for biyaene, it only appears for the active verb kerdene. Only active verbs can be passivized with the auxiliary verb (3.2b) (3.2d). The similarity between verbs can make it difficult to distinguish between Patient and Recipient. Boax kerdene is a transitive verb (3.2e), boax pı ra kerdene (3.2c) is a ditransitive verb. Boax in a transitive sentence (3.2e) is a component of the verb and belongs to the VP, while it functions as a direct object (3.2c) adjoining to the NP in a sentence with three arguments. As syntactic units, these elements have different functions. It is not normally possible for these elements to be replaced. When they change, the meaning of the sentence may collapse or the sentence may become completely meaningless. When the sentence Xıdıri dês kerd boax "Xıdır threw the wall in the paint" is compared to (3.2e), the difference in meaning becomes clear. Xıdıri dês kerd boax is structurally more close to (3.2a). The verb of both sentences is $\mathrm{Cl}$ kerdene "to put in". Even if the sentence has a meaning after the change in the position of constituents, the number of valence will change. It is not allowed to change the position of constituents in ditransitive sentences except the verbs that take the prefixes $\mathrm{Cl} \mathrm{ra}$ and $\mathrm{Cl}$ rê in Zazaki. The word order of these exceptional verbs is also different from usual ditransitive verbs. The word order of ditransitive A T V R, including $C l$, turns into the A T R V order only when used with combinations of $c l r a$ and $c l r e ̂$. It is possible to change the positions of the $\mathrm{T}$ and the $\mathrm{R}$ in this exceptional situation. Compared to (3.2a), Heseni uxwe est-e kemere 'Hesen threw water to the stone' has a completely different meaning. The meaning of the sentence after the replacement of the elements depends on the verb used in the sentence and its arguments. After the movement of the constituents, the meaning of the sentence depends on the verb and its arguments in the sentence.

\subsection{Relativization}

The relativization that occurs with the combination of the copular verb and the lexeme ke indicates the fetaures of a constituent. Since the lexeme ke has many different grammatical functions, the distinction should be made carefully. The lexeme ke which 
functions as a conjunction and a subjunctive mood particle is used with the verb biyaene for the relativization. The $\mathrm{T}$ and the $\mathrm{R}$ can be relativized in ditransitive sentences and the $\mathrm{P}$ in transitive sentences.

a. Malim kitab da-n-o talebe-y

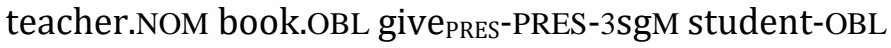
AGENT
THEME
RECIPIENT

'The teacher gives the book to the student.'

$\begin{array}{llll}\text { b. Malim-o ke kitab da-n-o cl } & \end{array}$

teacher.NOM-COP.3SGM REL book.OBL give PRES-PRES-3SgM TP.OBL

'The teacher who gives the book to him.'

c. Kitabo ke malim dano $\mathrm{cl}$ 'The book that the teacher gives to him.'

d. Kitabo ke dino cl 'The book which is given to him.'

e. Talebeo ke, malim kitab dano cı 'The student whom the teacher gives the book [REFERENCE].'

f. Talebeo ke, kitab dino cl 'The student who is given the book [REFERENCE].'

g. Malim kitab dano talebey ke, [] talebe biwano. 'The teacher gives the book to the student so that the student reads.'

Compared to (3.3b), the absence of copular verb in the sentence Malim ke kitab dano $\mathrm{Cl}$ 'if the teacher gives the book to him', which has the same meaning with the sentence Eke malim kitab dano $\mathrm{Cl}$, has attributed the function of conjunction to ke. In (3.3d), the recipient object pronoun is a component of the verb. This is because it is in VP. If the relative pronoun appears in the NP, it also needs the copular verb for this function. Otherwise, it moves to the end of the phrase for the complement and provides the connection with the next clause (3.3g). There is no functional difference in passive structures (3.3d) (3.3f). Likewise, $\mathrm{Cl}$ performs the same function as the reference constituent.

Figure 3.1. Relativization

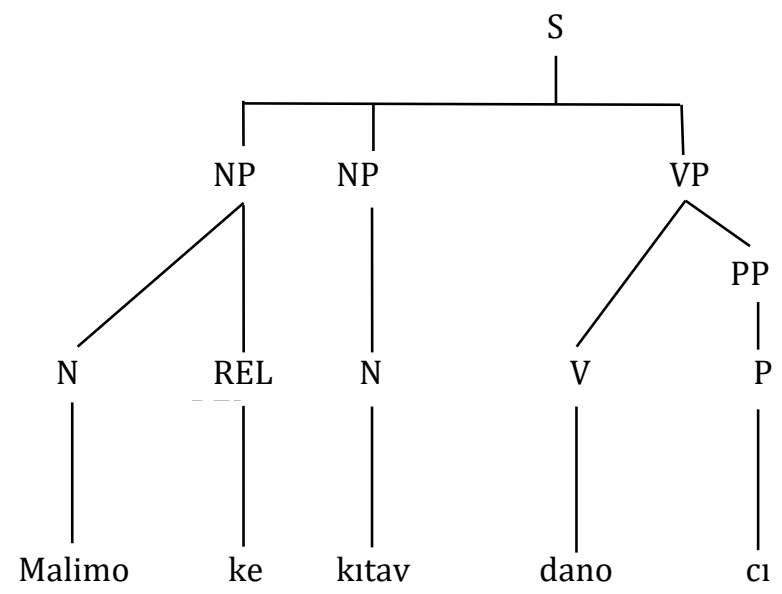




\subsection{Constituent Questions, Reflexivization, Reciprocalization}

The ditransitive structure can be questioned with the interrogative pronouns çl or kam. If any sounds appear after $c ̧ l$, the sound /- $k$ / or /-t / is added: $c ̧-k-o, c ̧ l-t-o$ 'what is?'. It is also used the pronoun se for $c ̧ l$ in the sentences that the verbs such as $\mathrm{Cl}$ ra vatene 'to say someone' are used. The recipient pronoun can be replaced by the reciprocal pronoun zumini 'each other' or reflexive xo/ho 'self' in the verbs such as $\mathrm{Cl} \mathrm{ra}$ vatene 'to say someone' and pı ra kuyaene 'to hit someone, something' that the direct object as a null object is not mostly pronounced.

a. Lazeki uẋwe kerde suse

'The boy put the water into the bottle.'

b. Kami çı kerd çık'

Who put what into what?'

c. Çı bi suse ‘

What happened to the bottle?'

d. Gule Sefkani ra qesey vati

'Gule scolded Sefkan'.

e. Ae ve ey ra zumini ra qesey vati

'She and he scolded each other'.

f. İne [] kuya zumini ra

'They bumped into each other'.

g. İne i kuyay zumini ra

'They bumped them into each other'.

h. İne i kuyay xo ra

'They bumped them to themselves'.

i. Ey torzên da xo ro 'He hit ax to himself'. $\quad$ xo ro daene 'to hit' cl kerdene 'to put'

cl biyaene 'to happen'

cl ra vatene 'to scold'

zumini ra vatene 'to scold each other'

zumini ra kuyaene 'to bump into'

zumini ra kuyaene "to bump into'

xo ra kuyaene 'to bump into'

Both the reciprocal and the reflexive pronoun can replace the recipient object pronoun according to the semantic content of the verbs that are combined with the recipient pronouns and the directional particles such as $p l r a$ and $t ı$ ro. The reflexive pronoun generally requires a directional particle. The conversion from reciprocal $(3.4 \mathrm{~g})$ to relativization $(3.4 \mathrm{~h})$ occurs properly. Although these pronouns are used in the infinitive form in the verbs reciprocal (3.4g) and relativization $(3.4 \mathrm{~h}),(3.4 \mathrm{i})$, the main verb is $\mathrm{pl} r \mathrm{ra}$ kuyaene. Thus, the contextual properties of the pronoun $p l$ are automatically reflected in the reciprocal and relativization sentences.

\subsection{Nominalization}

The infinitive forms of all inflected verbs including ditransitive ones can be converted into a noun by combining through the NP and Ezafe 'genitive' in the sentence. There are two types of infinitives in Zazaki, one being feminine kerdene 'to do, to make' and the other 
masculine kerdiş 'to do, to make'. These infinitives appear as alternations except in some specific cases in the Northern dialect. In the Southern dialect, only the masculine infinitive is used. If any suffixes appear after the feminine affix of the verb, this suffix drops and is replaced by /- $\varnothing /$. The suffix /-ê/ in the masculine and plural forms and the suffix /-a / in the feminine, provides the link: Kerd-en-a to 'your doing', kerd-ıs-ê to 'your doing' are semantically the same. The nominalization of the sentences in (3.4) are below.

(3.5) Nominalizition

a. [Lazeki] [uxiwe] [kerde suse] $\rightarrow$ [uxiwe cı kerdena lazeki]

'The boy put the water into the bottle.'

NP $\quad$ NP $\quad$ VP(V, NP) $\quad \rightarrow$ NP

b. [Gule] [[Sefkani ra] [qesey vati]] $\rightarrow$ [cı ra vatisê]

'Gule scolded Sefkan.'

NP $\quad \operatorname{VP}(((P P(N P, P)) \operatorname{VP}(N P, V)) \rightarrow$ NP

c. [Ae ve ey ra] [[zumini ra] [qesey vati] $\rightarrow$ [zumini ra qesey vatisê ine]

'She and he scolded each other.'

$\mathrm{PP}(\mathrm{PP}, \mathrm{PP}) \quad \mathrm{PP}(\mathrm{NP}, \mathrm{P}) \mathrm{VP}(\mathrm{NP}, \mathrm{V}) \quad \rightarrow \mathrm{NP}$

d. İne kuya zumini ra

$\rightarrow$ [zumini ra kuyaena/kuyayısê]

'They bumped into each other.'

NP VP (V PP(NP,P), $\quad \rightarrow$ NP

VP and NP turn into a NP by adjoining in nominalization. The recipient takes its position with the verb in the first position of Ezafe to be presented by $\mathrm{Cl}$. [Lazeki] (NP) [uxiwe] $(N P)$ [kerde suse] (VP) nominalizes with [uxiwe cı kerdena lazeki] (NP). Reciprocal zumini or reflexive $x o / h o$ may appear for $\mathrm{Cl}$. In other words, ditransitive verb becomes nominal and links with the suffix Ezafe to Agent. Thus, a new NP is formed.

\section{Semantic Description}

The word order in ditransitive verbs is normally A T V R. Cı ra, which has a peculiar feature and is used with benefactive verbs, precedes the verb because the starting position of its motion is the recipient object: A T R V. The word order in cl ra vatene ve cl ra hesnaene in these groups of verbs exceptionally becomes A R T V. The reason for this is that there is no physical action. In terms of semantic roles, one would say that 'give'-verbs take a recipient, while 'send'-verbs take a goal argument (Malchukov 2010: 48).

\subsection{0uter Pronouns}

$C_{l}$ is also used for bidirectional motion, while $p_{l}$ and $t_{l}$ only have one directional motion from Theme to Recipient: $\mathrm{T} \rightarrow \mathrm{R}, \mathrm{R} \rightarrow \mathrm{T}$. While $p ı$ appears in the actions that end on the surface of the recipient, it is possible to continue the action in $\mathrm{Cl}$ and $\mathrm{t}$.

a. pı ra: The motion that the A triggers with the $\mathrm{T}$ can continue for a while after it arrives on the surface of the $\mathrm{R}$.

b. pl ro: The only difference from pl ra is that the direction of the motion is from top to bottom. 
c. tı ra: It refers to the situation in which the Theme passes into or through the Recipient, passing the surface of the Recipient.

d. $t$ r ro: The only difference from $t ı r a$ is that the direction of the motion is from top to down.

e. $c$ r $r$ : There is a bidirectional motion: $\mathrm{T} \rightarrow \mathrm{R}, \mathrm{R} \rightarrow \mathrm{T}$.

a. Pisinge mor lone ra vet- $\varnothing$

cat.OBL snake.NOM hole.OBL DIR takePAST.3sgM off

Cl ra vetene

AGENT THEME RECIPIENT

'The cat took the snake out of the hole.'

b. Xeyzane qolonya kerd-e dest-un-ê xo ra pı rakerdene

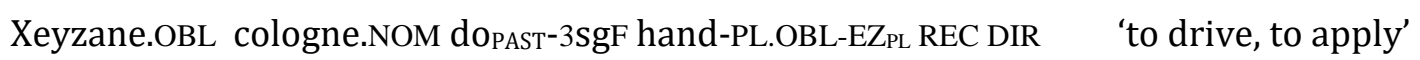

\section{AGENT THEME RECIPIENT}

'Xeyzane applied cologne on her hands'.

c. Moae uxiwe kerd-e çêneke ro

pı ro kerdene

mother.OBL water.NOM doPAST-3sgF girl.OBL DIR

'to pour off down'

AGENT THEME RECIPIENT

'The mother bathed the girl.'

d. Kokıkıe desteke kerd-e derẓêni ra

old woman.OBL rope.NOM doPAST-3sgF needle.OBL DIR

tı ra kerdene

AGENT THEME RECIPIENT

'The old woman threaded the needle.'

e. Dewiz-u genim kerd- $\varnothing$ patose ro tı ro kerdene

villager-PL.OBL wheat.NOM doPAST-3sgF machine.OBL DIR 'to throw down'

AGENT THEME RECIPIENT

'The peasants threw the wheat into the machine.'

$\begin{array}{lllll}\text { f. Ciranan } & \text { xele } & \text { da } & \text { patose } & \text { ru }\end{array}$

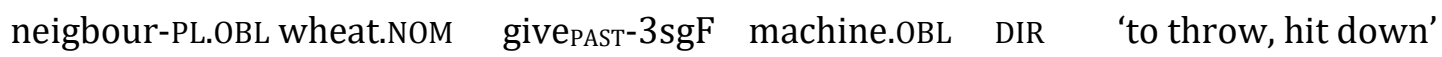

$\begin{array}{lll}\text { AGENT } & \text { THEME }\end{array}$

'The neigbours threw the wheat to the pest.'

g. Kam-i [ ] ti ra va? tı ra vatiş

who-OBL [] 2SG DIR sayPAST-3sgF 'to say'

AGENT THEME RECIPIENT

'Who said to you.' 
Cl $\mathrm{ra}$, which precedes the verb, both expresses bidirectional motion and allows some constituents to change their positions in the sentences that it is used. To compare (4.1a) pisinge mor lone ra vet does not make a semantic difference. The constituent of intonation only changes. Pisinge mor lone ra vet (4.1a) refers to an action from the recipient to the direct object. On the contrary, Malimi talebeu ra çiye vat 'The teacher told something to students' refers to an action from the direct object to the recipient. In the verb tı ra vatış ( cl ra vatene in the Northern dialect), which is used differently in the Southern dialect, direct object is not used as in the Northern dialect. These types of the verbs with null objects are so common in Zazaki. Although the null object is not used in the sentence, the verb is inflected according to the null object, which is always $3 \mathrm{sgM}$ in the past tense.

\subsection{Inner Pronouns}

The pronouns pe and te which cannot be used with a verb and can only be combined with directional de mostly signify the locality as a thematic role. Te de is mostly used in intransitive verbs, whereas pe de appears in a few ditransitive sentences.

pe de: It refers to the situation where the theme goes beyond the surface of the recipient and passes into it. te de: It is used for a closed area.

(4.2) Inside pronouns

a. Mêse [] da-Ø çêneke de

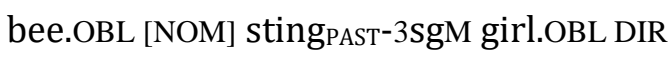
AGENT THEME RECIPIENT

'The bee stung the girl.'

b. Doman-u suse de uxiwe nê-verd-e child-PL.OBL bottle DIR water-NOM NEG-PAST-3SgF

\section{AGENT LOC THEME}

'The children left no water in the bottle.' pe de daene 'to sting, to bite'

te de verdaene

'to leave in'

The prefix also functions as a direct object in some verbs: It can be seen in examples in the table 4.1 how the recipient object pronouns make a ditransitive verb by adding a valence to a transitive verb. The direct object is empty in the verbs such as ci misnaene 'to show, to teach' that only the recipient pronoun is used as a suffix in the infinitive. Any nouns that are semantically appropriate can fill this position: derse cl misnaene 'to teach a lesson'. As for in some verbs such as pe de daene 'to stung someone', the direct object is literally null. Only in a grammatical analysis, it is understood that the direct object is metaphorically used as 3sgM. The direct object in the sentences with such verbs is never used explicitly. It is always null in these structures (4.1a).

Some transitive and ditransitive verbs that are similar to each other are distinguished from each other due to the syntactic structure of the sentence. The recipient object pronoun is also used in ditransitive verbs.

Sefkani kar kerd $\quad \rightarrow$ kar kerdene 'to work', tr. (A,P)

'Sefkan worked.'

Xıdıri Sefkani kerd kar $\rightarrow$ kar (cl) kerdene 'to help someone get a job, ditr. (A,T,R) 
'Xıdır helped Sefkan get a job.'

In the table 4.1 below, some transitive verbs are given along with ditransitive verbs to indicate the differences.

Table 3.1.Properties of ditransitive verbs

\begin{tabular}{|c|c|c|c|c|c|c|c|}
\hline PREV & $\mathrm{IO}$ & DIR & DO & PREV & VERB & VAL & MEANING \\
\hline & $\mathrm{Cl}$ & rê & $\varnothing$ & & ardene & 3 & to bring for someone \\
\hline \multirow[t]{12}{*}{ ero } & $\mathrm{Cl}$ & & $\varnothing$ & & ardene & 3 & to adapt someone/something \\
\hline & $\mathrm{tl}$ & ro & $\varnothing$ & & cinitene & 3 & to sop, to dip someone/something \\
\hline & & & & gos & daene & 2 & to hear \\
\hline & & & veng & & daene & 2 & to call someone \\
\hline & & & $\varnothing$ & dêm & daene & 2 & to overturn someone, something \\
\hline & $\mathrm{Cl}$ & & $\varnothing$ & & daene & 3 & to give someone \\
\hline & $\mathrm{Cl}$ & & ṗoşti & & daene & 3 & to support someone/something \\
\hline & $\mathrm{Cl}$ & & veng & & daene & 3 & to call someone \\
\hline & $\mathrm{Cl}$ & & zere & & daene & 3 & to fall in love \\
\hline & pe & de & $\varnothing$ & & daene & 3 & to sting someone \\
\hline & pl & ro & $\varnothing$ & & daene & 3 & to hit someone/something \\
\hline & pl & ra & $\varnothing$ & & daene & 3 & to dress up someone \\
\hline \multirow[t]{3}{*}{ ero } & $\mathrm{Cl}$ & & $\varnothing$ & & dardene & 3 & to trouble someone \\
\hline & $\mathrm{Cl}$ & & $\varnothing$ & & estene & 3 & to throw someone/something \\
\hline & $\mathrm{Cl}$ & & $\varnothing$ & & fiştene & 3 & to sting, to insert someone/something \\
\hline \multirow[t]{16}{*}{ era } & $\mathrm{Cl}$ & & $\varnothing$ & & fiştene & 3 & to burn fire \\
\hline & $\mathrm{Cl}$ & ra & $\varnothing$ & & guretene & 3 & to receive, to buy \\
\hline & pi & ra & $\varnothing$ & & guretene & 3 & to wear something \\
\hline & $\mathrm{Cl}$ & ra & $\varnothing$ & & hesnaene & 3 & to hear from someone \\
\hline & $\mathrm{Cl}$ & ra & & has & kerdene & 3 & to love someone \\
\hline & $\mathrm{Cl}$ & & $\varnothing$ & & kerdene & 3 & to put into someone/something \\
\hline & $\mathrm{Cl}$ & ra & $\varnothing$ & & kerdene & 3 & to snatch, cut off something \\
\hline & $\mathrm{Cl}$ & ra & $\varnothing$ & pers & kerdene & 3 & to ask someone \\
\hline & pe & de & $\varnothing$ & & kerdene & 3 & to sting something \\
\hline & pl & ra & $\varnothing$ & & kerdene & 3 & to rub someone/something \\
\hline & $\mathrm{tl}$ & ro & $\varnothing$ & & kerdene & 3 & to throw into someone/something \\
\hline & $\mathrm{tl}$ & ra & $\varnothing$ & & kerdene & 3 & to attach someone/something \\
\hline & pi & ra & $\varnothing$ & & kuyaene & 3 & to crash someone/something \\
\hline & $\mathrm{Cl}$ & & $\varnothing$ & & misnaene & 3 & to show someone \\
\hline & $\mathrm{Cl}$ & ro & gos & & naene & 3 & to harken someone/something \\
\hline & pl & ra & $\varnothing$ & & naene & 3 & to touch, to contact someone/something \\
\hline \multirow[t]{8}{*}{ ede } & $\mathrm{Cl}$ & & $\varnothing$ & & pernaene & 3 & to sting something \\
\hline & pl & ro & $\varnothing$ & & pilosnaene & 3 & to wrap up someone/something \\
\hline & $\mathrm{Cl}$ & & $\varnothing$ & & risnaene & 3 & to sprinkle something \\
\hline & $\mathrm{Cl}$ & & $\varnothing$ & & sanaene & 3 & to crash, to bump something \\
\hline & $\mathrm{Cl}$ & ra & $\varnothing$ & & vatene & 3 & to say, to tell someone \\
\hline & $\mathrm{tl}$ & ra & $\varnothing$ & & vatış & 3 & to say, to tell someone/something \\
\hline & $\mathrm{Cl}$ & ra & $\varnothing$ & & vetene & 3 & to extract something \\
\hline & pl & ra & $\varnothing$ & & zeleqnaene & 3 & to paste someone/something \\
\hline
\end{tabular}




\section{Conclusion}

Ditransitive verbs that causes a change of case in Zaza language do not allow the replacement of the constituents in the $\mathrm{A} \mathrm{T} \mathrm{V} \mathrm{R} \mathrm{order.} \mathrm{In} \mathrm{ditransitive} \mathrm{verbs} \mathrm{where} \mathrm{the}$ direction of the motion is from Recipient to Theme, the constituents are ordered in the $A$ $\mathrm{T} \mathrm{R} V$ fashion. It is possible that the $\mathrm{T}$ and the $\mathrm{R}$ replace their positions in such sentences, and this replacement does not change the meaning of the sentence. There may be a difference only in the emphasized constituent. Regardless of whether the verb is transitive or intransitive, indirect objects, that is recipient, are always marked by oblique case. The recipient has no valence in intransitive verbs, but it is a requisite constituent in ditransitive verbs.

The recipient object pronouns used to represent the recipient are combined with verbs in connection with their semantic content. These pronouns can make the meaning of the verb specific: kerdene 'to do', cr kerdene 'to do inside'. Furthermore, they can attribute a completely different meaning to the verb: daene 'to give' $\rightarrow$ pl ra daene 'to dress up someone'.

Although some recipient object pronouns are used in different meanings in the Southern dialect, they do not change the ditransitive feature of the verb. Semantic and morphological differences do not affect syntax.

\section{Abbrevitations}

A: Agent, DIR: Directional, ditr.: ditransitive, DO: Direct object, int.: intransitive, IO: Indirect object, LOC: local, NOM: Nominative, Ø: Zero morpheme, OBL: Oblique, P: Patient, PL: Plural, pl: plural, PRES: Present, PREV: Preverbal, PRON: Pronoun, R: Recipient, SG: Singular, sg: singular, T: Theme, tr.: transitive, V: Verb, VAL: Valence. 


\section{Kaynakça}

Arslan, İlyas. "Partikeln in Zazaki”. Unpuslished master thesis: Köln: Universität zu Köln. 2007. https://www.academia.edu/45028958/Partikeln_im_Zazaki.

Arslan, Ilyas. "Ergativität und Verbfunktionalität in der Zaza Sprache". PhD Thesis: Düsseldorf: Universität Düsseldorf. 2016. https://docserv.uniduesseldorf.de/servlets/DerivateServlet/Derivate39270/Arslan_Dissertation_Submit_Bib_A1.pdf.

Arslan, Ilyas. 'Zaza Dilindeki ergatif sistemin tarihi gelişimi". Munzur Üniversitesi Sosyal Bilimler Dergisi 4(8) (2017): 63-87.

Durscheid, Christa. Verbsyntax und Rollensemantik. In Deutsche Sprache: ds; Zeitschrift für Theorie, Praxis, Dokumentation. 29(2) (2001): 176-185.

Faghiri, Pegah \& Samvelian, Pollet \& Hemforth, Barbara. "Accessibility and Word Order: The Case of Ditransitive Constructions in Persian". In Stefan Müller (Ed.): Proceedings of the 21st International Conference on Head-Driven Phrase Structure Grammar, University at Buffalo (pp. 217-237). Stanford, CA: CSLI Publications. 2014.

Malchukov, Andrej, Haspelmath, Martin and Comrie, Bernard. Studies in Ditransitive Constructions: A Comparative Handbook, Berlin, New York: De Gruyter Mouton, 2010. https://doi.org/10.1515/9783110220377

Haspelmath, Martin. "Ditransitive constructions: Towards a new Role and Reference Grammar account?" İn Investigations of the Syntax-Semantics-Pragmatics Interface. Ed. Van Valin, R Jr., 75-100 (2008). 10.1075/slcs.105.09has.

Haspelmath, Martin. "Ditransitive constructions". In Annu. Rev. of Linguist. 1 (2015):1941 https://www.annualreviews.org/doi/abs/10.1146/annurev-linguist-030514125204.

Plank, Frans. Direkte indirekte Objekte. Oder: Was uns lehren lehrt. Leuvense Bijdragen 76. (1987): 37-61.

Selcan, Zülfü. Grammatik der Zaza-Sprache: Nord-Dialekt (Dersim-Dialekt). Berlin: Wissenschaft \& Technik. 1998.

Van Valin, Robert D., Jr. "The Role and Reference Grammar Analysis of Three-Places Predicates". Suvremena Lingvistika 33.1.63. 2007: 31-64. 